\title{
EFFECT OF ULTRASOUND TREATMENT ON PARTICLE SIZE, RHEOLOGY, MICROSTRUCTURE, COLOUR AND WATER HOLDING CAPACITY OF A SOY-BASED DESSERT
}

\author{
J.C. SpadA*, L.D.F. Marczak, I.C. Tessaro and N.S.M. Cardozo \\ Chemical Engineering Department, Federal University of Rio Grande do Sul, Engenheiro Luiz Englert Street, \\ Porto Alegre/RS 90040-040. Brazil
}

(Received: 16 March 2015; accepted: 3 June 2015)

\begin{abstract}
Power ultrasound has vast potential in the food industry; however, there are no works on its effects on desserts. Thus, the objectives of this study were to investigate the effect of ultrasound as a mixing or homogenization step or as a tool to modify the texture of the soy-based desserts without reformulating the product. Different properties of soybased desserts were evaluated and the behaviour of the samples during storage under refrigeration (60 days) was monitored. The samples were treated with an ultrasound probe for 1, 3, and $5 \mathrm{~min}$. The treated samples showed lower mean particle size, lower consistency index, higher flow index, and clear difference in their microstructure. However, water holding capacity and particle size dispersion index values did not differ among untreated and treated soy based desserts for 1 and 3 minutes, and none of the treatments caused visible colour differences among the samples. Periodically, rheological properties, $\mathrm{pH}$, soluble solids content, colour, particle size, and water holding capacity were determined. After 60 days, all evaluated properties differed significantly, except for the $\mathrm{pH}$.
\end{abstract}

Keywords: ultrasound, soy foods, rheology, desserts

High-power ultrasound is gaining importance as an alternative food processing technology, being used for different purposes. Examples include homogenization of milk (BERMUDEZAguiRRE et al., 2009a,b; CZANK et al., 2010), mixing step of cereal-based viscous fluids such as batter cake for texture improvement (TAN et al., 2011), reduction of the density of products, such as ice cream, mousse, and confectionary (LIM \& BARIGOU, 2005), and increase of the final product viscosity of tomato puree (BATES et al., 2006).

Regarding specifically soy-based desserts, to the best of our knowledge, there is no study in the literature evaluating the effect of ultrasound on the texture and stability of this type of product. However, some individual components of soy-based desserts (soy, starches, and other polysaccharides) have already been treated with ultrasound and its effect on different properties was examined.

JAMBRAK and co-workers (2009) have studied the influence of ultrasound treatment on physical properties of soy protein isolates and concentrates, reporting that in both cases the treatment with $20 \mathrm{kHz}$ probe (for 15 or $30 \mathrm{~min}$ ) increased solubility, emulsion activity index, and specific surface area of the samples, with the two latter effects being advantageous in terms of food texture. Ultrasonic treatment has also been applied to corn, potato, tapioca, and sweet potato starches (Huang, et al., 2007; Luo et al., 2008; JambraK et al., 2010; Montalbo-Lomboy et al., 2010; SUJKA \& JAMrOZ, 2013), gelatinized starches (IIDA et al., 2008), and solutions of other polysaccharides (LiI et al., 1999, IIDA et al., 2008; AzIZI \& FARAHNAKy, 2013). The authors have reported decrease in viscosity, molecular weight, and particle size values of the treated

\footnotetext{
* To whom correspondence should be addressed.

E-mail: jcorralospada@yahoo.com.br
} 
samples, and have attributed these results to depolymerisation processes resulting in partial cleavage of glycosidic linkages in amylopectin and amylose units (IIDA et al., 2008).

Taking into account the information above, the ultrasound has potential to be used as a mixing or homogenization step or to improve the texture of the soy-based desserts, since it is capable of modifying important properties of starches, polysaccharides, and soy protein solutions. In this study, the effects of the ultrasonic process on soy-based desserts has been evaluated by measuring the changes in $\mathrm{pH}$, soluble solids content, viscosity, colour, water holding capacity, and microstructure of the samples.

\section{Materials and methods}

\subsection{Material and sample preparation}

The ingredients used in the formulations included water-soluble soy extract (Olvebra Industrial S/A, Eldorado do Sul, Brazil), sucrose (União, Limeira, Brazil), carboxymethyl cellulose (CMC) (Hexus Food, Portão, Brazil), powdered guava juice (Kraft Foods, Curitiba, Brazil), carrageenan (Cargill Alimentos, Minnesota, United States), polydextrose (Danisco Brasil Ltda, Cotia, Brazil), cross-linked corn starch (Snow flake@ 6308, Corn Products Brasil Ingredientes Industriais, Mogi-Guaçu, Brazil), and guava pulp (Mais Fruta, Antônio Prado, Brazil). The commercial guava pulp used in this work presented $\mathrm{pH}$, soluble solids content, and moisture value of $3.94 \pm 0.04,7.00 \pm 1.00$ and $93.78 \pm 0.07$, respectively. The physicochemical composition of the soy extract was $10 \%$ of moisture, $18.5 \%$ of carbohydrates, $44 \%$ of protein, $26 \%$ of fat, and $1.5 \%$ of fibre.

Soy-based dessert was prepared similarly to SPADA and co-workers (2014) as follows: i) hydration of water-soluble soy extract in water at $40{ }^{\circ} \mathrm{C}$ for $15 \mathrm{~min}$ at 100 r.p.m. using a propeller stirrer; ii) addition of dry ingredients to the soy solution at 1000 r.p.m. for 15 min; iii) addition of the gelatinized starch and of the guava pulp under agitation (1000 r.p.m.) for $10 \mathrm{~min}$; iv) ultrasonication; v) pasteurization at $75^{\circ} \mathrm{C}$ for $30 \mathrm{~s}$; vi) filling into sterilized glass containers; and vii) storage at $7 \pm 1^{\circ} \mathrm{C}$ for $24 \mathrm{~h}$ prior to their evaluation. The starch used in step (iii) was previously gelatinized in a water-bath at $100{ }^{\circ} \mathrm{C}$ for $5 \mathrm{~min}$ to provide total gelatinization.

The ingredients and quantities ( $\mathrm{g} / 100 \mathrm{~g})$ used in the formulation were: sucrose (9), guava pulp (16.5), water soluble soy extract (6.5), modified starch (3.7), polydextrose (2), powdered guava juice (1.5), carboxymethyl cellulose (0.4), carrageenan (0.3), and mineral water (quantum sufficit for $100 \mathrm{~g}$ ). Desserts were sonicated in $100 \mathrm{~g}$ aliquots in $250 \mathrm{ml}$ glass vessel, using a $20 \mathrm{kHz}, 750 \mathrm{~W}$ ultrasonic probe $(12 \mathrm{~mm}$ diameter, Sonics Vibracell, model VC750, Newtown, USA), for $1 \mathrm{~min}$ (US-1), $3 \mathrm{~min}$ (US-3), and $5 \mathrm{~min}$ (US-5). The ultrasonic density was $3 \mathrm{~W} \mathrm{~g} \mathrm{~g}^{-1}$ and to promote a better homogenization of the sample, every $30 \mathrm{~s}$ it was stirred using a mechanical stirrer.

It is noteworthy that after 60 days the samples were in accordance with the Brazilian microbiological standard of foods (BRASIL, 2001).

\subsection{Physicochemical and microstructural properties}

Soluble solids content (SSC) was measured with a refractometer at $25{ }^{\circ} \mathrm{C}$ (AOAC, 2000a), $\mathrm{pH}$ using a pH-meter (AOAC, 2000b), water holding capacity using the centrifuge method 
(HARTE et al., 2003) and microstructural properties were conducted with optical microscopy with magnification of $\times 40$ (SPADA et al., 2014).

\subsection{Particle size distribution}

The non-soluble material in the samples was characterized with relation to particle size distribution using laser diffraction (Cilas 1180 Liquid; Cilas Corporate, France) in wet mode using distilled water as carrier liquid. To perform the measure, the following parameters were used: refractive index of the sample (1.36), sample amount (400 mg), distilled water amount ( $2 \mathrm{ml}$ that was introduced using a pipette) and ultrasound time before the measurement (60 s). Before introduction into the equipment, the samples were dispersed in distilled water in a ratio of 1:10 w/v. The volume mean diameter $\left(D_{4,3}\right)$ and the dispersion index (span) were calculated.

\subsection{Colour measurement}

Colour was measured in a colorimeter (Konica Minolta Sensing Inc., CR 400, Japan) using optical glass cells $2 \mathrm{~cm}$ high with a diameter of $6 \mathrm{~cm}$. The colour reader was calibrated using a calibration plate CR A43. Results were expressed using the CIE $L * a * b *$ colour space with reference to illuminant D65 and a visual angle of $10^{\circ}$. From $L^{*}, a^{*}$, and $b^{*}$ the colour difference $\left(\Delta E^{*}\right)$ was calculated.

\subsection{Rheological behaviour}

A rotational rheometer (Ares, TA Instruments, New Castle, USA) was used to conduct rheological measurements (steady and dynamic tests) using a plate-plate geometry $(50 \mathrm{~mm})$ with a gap of $1.5 \mathrm{~mm}$. Flow curves (shear stress versus shear rate) were obtained from 0.1 to $300 \mathrm{~s}^{-1}$. The hysteresis area was measured as the area between the up and down curves, and these values were normalized by the area of the increasing shear rate stage of the respective flow curve. The hysteresis curve is a measure of the extent the structural breakdown caused by shear stress. This behaviour is typical of thixotropic fluid; the larger the area under the curve, the greater the thixotropic effect.

Data from the downward curve of the shear cycle measured at $25{ }^{\circ} \mathrm{C}$ were fitted to Ostwald-de Waele model ( $\tau=K \dot{\gamma}^{n}$, where: $\tau$ is the shear stress, $\dot{\gamma}$ is the shear rate, $K$ is the consistency index, and $n$ is the flow index). The parameters were estimated by the leastsquare method, using the software Statistica 10.0 (Statsoft Inc., Tulsa, OK, USA). Dynamic frequency sweeps (elastic $\left(G^{\prime}\right)$ and viscous $\left(G^{\prime \prime}\right)$ moduli versus frequency) were also carried out at $25^{\circ} \mathrm{C}$ in the range of $0.5-500 \mathrm{rad} \cdot \mathrm{s}^{-1}$. These tests were performed to calculate the ratio between the moduli $\left(G^{\prime} / G^{\prime \prime}\right)$ that provides information about the strength of the gel.

\subsection{Statistical analysis}

For the statistical analysis, analysis of variance (ANOVA) and Tukey's test were performed using the software Statistica for Windows (version 12, StatSoft, USA). A P-value below 0.05 was considered significant. 


\section{Results and discussion}

The values of volumetric diameter (D4,3), span, $\mathrm{pH}, S S C, W H C$ at $7^{\circ} \mathrm{C}$ and $25^{\circ} \mathrm{C}$, rheological parameters, and total colour difference after 60 days are shown in Table 1 . It can be noted that the ultrasonic treatment affected the size distribution of the non-soluble material in the formulation, since the mean particle size $(D 4,3)$ varied significantly between untreated and treated samples and with the time of treatment according to the Tukey's test $(\mathrm{P}<0.05)$. These results are in accordance with that reported by JAMBRAK and co-workers (2009) for soy protein (isolate and concentrate) and by JAMBRAK and co-workers (2010), who analysed the weight mean diameter of starches.

Table 1. Properties of the samples at first day and after 60 days of storage

\begin{tabular}{|c|c|c|c|c|c|c|c|c|}
\hline \multirow{2}{*}{ Properties } & \multicolumn{2}{|c|}{ Untreated } & \multicolumn{2}{|c|}{ US-1 } & \multicolumn{2}{|c|}{ US-3 } & \multicolumn{2}{|c|}{ US-5 } \\
\hline & 1 & 60 & 1 & 60 & 1 & 60 & 1 & 60 \\
\hline $\mathrm{pH}$ & $5.06^{\mathrm{a}}$ & $5.01^{\mathrm{a}}$ & $5.04^{\mathrm{a}}$ & $4.97^{\mathrm{a}}$ & $5.03^{\mathrm{a}}$ & $4.97^{\mathrm{a}}$ & $5.09^{\mathrm{a}}$ & $5.05^{\mathrm{a}}$ \\
\hline $\mathrm{SSC}\left({ }^{\circ}\right.$ Brix $)$ & $19^{\mathrm{a}}$ & $19^{\mathrm{a}}$ & $20^{\mathrm{a}}$ & $20^{\mathrm{a}}$ & $21^{\mathrm{a}}$ & $19^{\mathrm{b}}$ & $22^{\mathrm{a}}$ & $20^{\mathrm{b}}$ \\
\hline $\mathrm{WHC}_{25^{\circ} \mathrm{C}}(\%)$ & $98.98^{\mathrm{a}}$ & - & $98.18^{\mathrm{a}}$ & - & $99.03^{\mathrm{a}}$ & - & $69.91^{\mathrm{a}}$ & - \\
\hline $\mathrm{WHC}_{7{ }^{\circ} \mathrm{C}}(\%)$ & $100^{\mathrm{a}}$ & $91.52^{\mathrm{b}}$ & $100.00^{\mathrm{a}}$ & $98.86^{\mathrm{b}}$ & $100^{\mathrm{a}}$ & $99.41^{\mathrm{b}}$ & $100^{\mathrm{a}}$ & $90.07^{\mathrm{b}}$ \\
\hline$\Delta \mathrm{E}^{*}$ & - & 3.44 & - & 3.06 & - & 2.98 & - & 3.46 \\
\hline $\mathrm{D}_{4,3}(\mathrm{~mm})$ & $33.69^{\mathrm{a}}$ & $26.71^{\mathrm{b}}$ & $31.49^{\mathrm{a}}$ & $26.27^{\mathrm{b}}$ & $30.99^{\mathrm{a}}$ & $26.65^{\mathrm{b}}$ & $28.63^{\mathrm{a}}$ & $26.52^{b}$ \\
\hline Span & $1.28^{\mathrm{a}}$ & $1.23^{\mathrm{a}}$ & $1.28^{\mathrm{b}}$ & $1.49^{\mathrm{a}}$ & $1.41^{\mathrm{a}}$ & $1.55^{\mathrm{a}}$ & $1.64^{\mathrm{a}}$ & $1.76^{\mathrm{a}}$ \\
\hline $\mathrm{K}_{25^{\circ} \mathrm{C}}(\mathrm{Pa} \mathrm{s})$ & $78.71^{\mathrm{a}}$ & $18.46^{\mathrm{b}}$ & $65.52^{\mathrm{a}}$ & $17.05^{\mathrm{b}}$ & $49.04^{\mathrm{a}}$ & $11.40^{\mathrm{b}}$ & $23.25^{\mathrm{a}}$ & $5.80^{\mathrm{b}}$ \\
\hline $\mathrm{n}$ & $0.277^{\mathrm{b}}$ & $0.423^{\mathrm{a}}$ & $0.293^{\mathrm{b}}$ & $0.445^{\mathrm{a}}$ & $0.332^{\mathrm{b}}$ & $0.466^{\mathrm{a}}$ & $0.405^{\mathrm{b}}$ & $0.535^{\mathrm{a}}$ \\
\hline $\mathrm{G}^{\prime} / \mathrm{G}^{\prime \prime}{ }_{(50)}(\mathrm{Pa})$ & $2.97^{\mathrm{a}}$ & $2.48^{\mathrm{b}}$ & $2.58^{\mathrm{a}}$ & $2.21^{\mathrm{b}}$ & $2.27^{\mathrm{a}}$ & $1.85^{\mathrm{b}}$ & $1.72^{\mathrm{a}}$ & $1.76^{\mathrm{a}}$ \\
\hline Hysteresis area $(\%)$ & $1.10^{\mathrm{b}}$ & $15.04^{\mathrm{a}}$ & $1.30^{\mathrm{b}}$ & $13.40^{\mathrm{a}}$ & $0.70^{\mathrm{b}}$ & $14.10^{\mathrm{a}}$ & $1.10^{\mathrm{b}}$ & $14.70^{\mathrm{a}}$ \\
\hline
\end{tabular}

*: For each sample, means within lines followed by different superscripts are significantly different at $\mathrm{P}<0.05 \mathrm{using}$ Tukey's test

On the other hand, the effect of the ultrasonic treatment on the width of the particle size distribution only became significant for the highest time of treatment tested (US-5, span=1.64). This result indicates that the ultrasound treatment led to the increase of the amount of small size particles in the sample, but not to increase of homogeneity in the particle size distribution, as corroborated by the micrographs of Figure 1. Moreover, both analysis showed that independently of the ultrasound time, the particles of large size ( $90 \mathrm{um})$ remained in the samples. A possible cause for this behaviour is the high viscosity of the dessert formulations studied, because the ultrasound absorption in a given medium increases when its viscosity increases, reducing the propagation of ultrasound waves (HuANG \& TERENTJEV, 2012). When compared to results reported by other authors, who have used high pressure homogenizers for different products, such as ice-cream (INNOCENTE et al., 2009), yoghurts (CIRON et al., 2010), and pineapple pulp (SiLVA et al., 2010), the ultrasound seems to be less effective in terms of homogenization of particle size. However, studies regarding energy density are necessary to compare the technologies. 
The ultrasound did not cause changes in the $\mathrm{pH}$ values of the samples. However, the soluble solids content (SSC) of the samples varied significantly (Table 1), ranging from 19 to $22{ }^{\circ}$ Brix. The higher soluble solids content of the US-treated samples may be taken as an indicative that particle size reduction discussed previously was accompanied by the release or leaching of soluble compounds due to structural changes or breaking of some components as proteins, starch, and polysaccharides. The result corroborates the reported findings by other authors (MASON \& ZhaO, 1994; Kresic et at., 2008; JAMBraK et al., 2010), who mentioned that the ultrasound effect is related to the disruption of cell tissues, allowing a better release of soluble constituents.
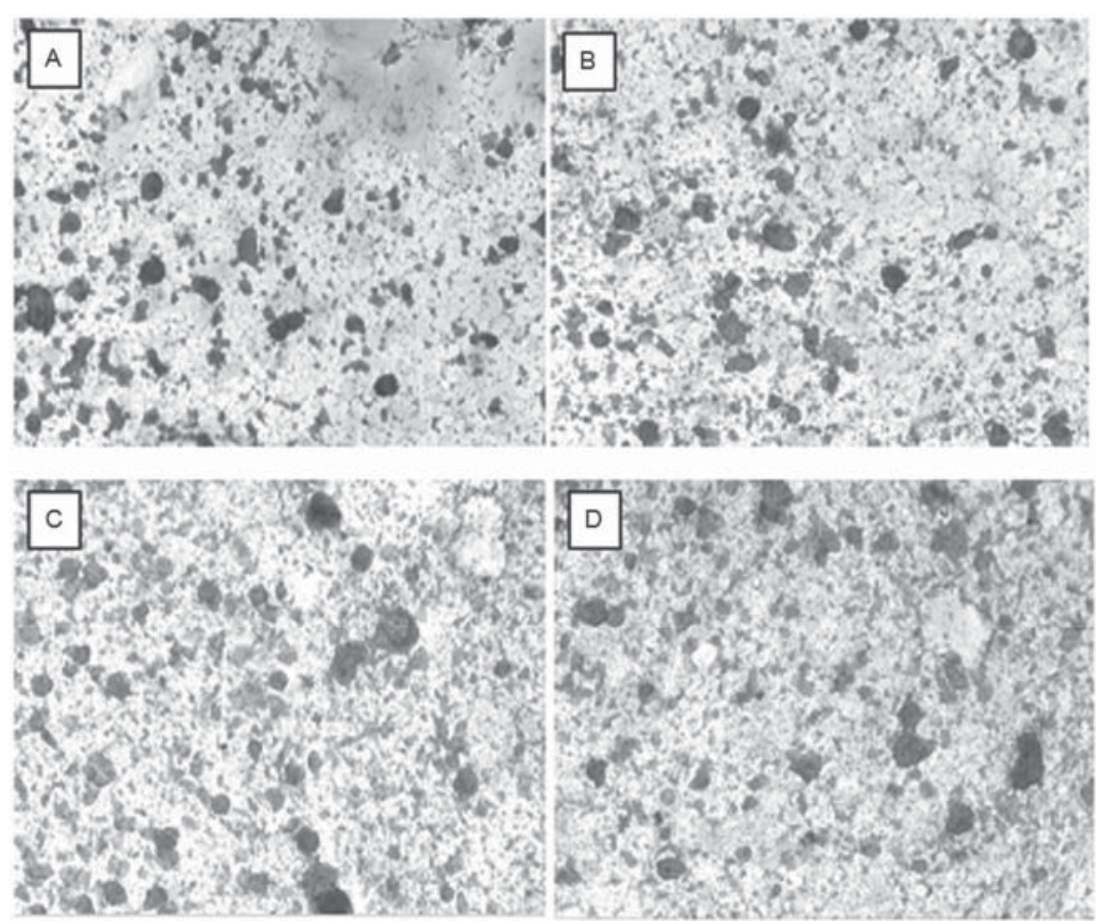

Fig. 1. Photomicrographs $(\times 40)$ of the untreated sample (A) and of the US-treated samples for $1 \mathrm{~min}(\mathrm{~B})$, $3 \min (\mathrm{C})$, and $5 \min (\mathrm{D})$

Rheologically, all desserts exhibited non-Newtonian behaviour with insignificant values of hysteresis area. The viscosity of the samples decreased with the increase of the time of treatment as indicated in Table 1 by the monotonous decrease of the consistency index. The increase of the flow index $(n)$ with the time of treatment is a direct consequence of the decrease of viscosity and particle size (discussed before) promoted by the ultrasound, since these two effects are expected to make the flow behaviour of a complex system closer to that of a Newtonian fluid. In the previous work (SPADA et al., 2014) the influence of the interactions between the components on the viscosity of the samples has been discussed. The interactions have been explained on the basis that protein-polysaccharides interactions and polysaccharideswater binds could be indirectly influenced by the water content. The lower the amount of water added in the initial step of the desserts production, the lower the steric hindrance, 
which facilitates the interactions among the molecules, increasing the viscosity of the food. Taking into account these considerations, there is the possibility that some of these interactions are broken during the sonication, leading to a lower viscosity.

Additionally, all samples showed a clear gel-like behaviour, with $G$ ' higher than $G$ ", over the entire frequency range (BRUMMER, 2006). For all cases the ratio was always lower than 3 in such a way that they can be classified as weak gels, according to the criterion of LAPASIN and PRICL (1995). Furthermore, the gel strength decreased with the time of treatment, consistently with the effect of this parameter on the viscosity of the system. The lower values of $G^{\prime} / G^{\prime \prime}$ at $50 \mathrm{rad} \mathrm{s}^{-1}$ and consistency index $\left(K_{25}{ }^{\circ}\right)$ of the ultrasonicated samples indicate that the ultrasound treatment leads to a more open molecular network with lower density strands and gel junction zones in the microstructure.

Regarding physical stability, all samples presented $W^{\circ} C_{7{ }^{\circ} \mathrm{C}}=100 \%$, retaining all free water in the food matrix. However, the $W H C_{25}{ }^{\circ} \mathrm{C}$ behaved differently (Table 1). The samples treated for 1 and 3 min presented $W H C_{25}{ }^{\circ}$ Values statistically equal to untreated sample, unlike the sample treated for $5 \mathrm{~min}$, which presented a lower value. When the treated samples for 1 and $3 \mathrm{~min}$ are compared with that of the preceding paper (SPADA et al., 2014) with similar consistency index, it is possible to note that they present higher $W H C_{25{ }^{\circ} \mathrm{C}}$ values. In contrast, the treated samples for 5 min showed similar $W H C_{25}{ }^{\circ} \mathrm{C}$ value to samples with similar viscosity.

Table 2 shows the colour properties of the untreated and treated samples at the first day. As can be seen all samples presented low values of lightness (from 54.36 to 55.62), $a^{*}$ colour coordinate in the red axis (from 4.87 to 5.12 ) and $b^{*}$ colour coordinate in yellow axis (from 10.96 to 12.72$)$. The total colour difference $\left(\Delta E^{*}\right)$ between untreated and treated samples ranged between 0.31 and 2.03, showing that the ultrasound did not promote visible differences on colour attributes of the dessert formulation. In industrial perspective, $\Delta E^{*}$ values between 1.1 and 2.8 units in the CIELab scale are presented as a strict quality standard, values between 2.8 and 5.6 units are considered as a "normal" pattern and a "low-end" quality when $\Delta E^{*}$ values are greater than 5.6 units (Melgosa et al., 2001).

Table 2. Colour parameters of the untreated and treated samples

\begin{tabular}{|c|c|c|c|c|c|}
\hline \multirow[b]{2}{*}{ Samples } & \multicolumn{5}{|c|}{ Colour parameters } \\
\hline & \multicolumn{2}{|c|}{ Untreated } & US-1 & US-3 & US-5 \\
\hline$L^{*}$ & \multicolumn{2}{|c|}{$54.36 \pm 0.04$} & $55.37 \pm 0.01$ & $55.52 \pm 0.02$ & $55.62 \pm 0.02$ \\
\hline$a^{*}$ & \multicolumn{2}{|c|}{$4.87 \pm 0.01$} & $4.98 \pm 0.02$ & $4.83 \pm 0.01$ & $5.12 \pm 0.02$ \\
\hline$b^{*}$ & \multicolumn{2}{|c|}{$10.96 \pm 0.02$} & $12.72 \pm 0.01$ & $11.95 \pm 0.02$ & $11.93 \pm 0.01$ \\
\hline$\Delta E_{(\mathrm{UN} / \mathrm{US}-1)}^{*}$ & $\Delta E_{(\mathrm{UN} / \mathrm{US}-3)}^{*}$ & $\Delta E_{(\mathrm{UN} / \mathrm{US}-5)}^{*}$ & $\Delta E_{(\text {US-1/US-3) }}^{*}$ & $\Delta E_{(\text {US-1/US-5) }}^{*}$ & $\Delta E_{(\mathrm{US}-3 / \mathrm{US}-5)}^{*}$ \\
\hline 2.03 & 1.52 & 1.60 & 0.80 & 0.85 & 0.31 \\
\hline
\end{tabular}

After 60 days of cold storage, the untreated sample showed equal $\mathrm{pH}$ and $S S C$ values (Table 1). The shape of the particle distribution did not change (data not shown), but there was a slight shift in the distribution towards the smaller particle sizes on storage, resulting in a small decrease in the volume mean diameter $\left(D_{4,3}\right)$ from $33.69 \mathrm{~mm}$ to $26.71 \mathrm{~mm}$. The water holding capacity value differed significantly $(\mathrm{P}<0.05)$, however it remained high $(>90 \%)$. However, the rheological properties changed during the storage, with decrease of consistency 
index and $G^{\prime} / G^{\prime}$ ratio, showing lower strength of the gel network. Moreover, an increase was observed in the flow index and percentage of hysteresis area values that confirms the thixotropic behaviour of the samples, since they become less viscous just in repose along the time.

The colour of all samples after 60 days of storage can be considered equal to the initial value (first day of storage), since the $\Delta E^{*}$ values remained in the range of the normal standard, as commented before.

\section{Conclusions}

It can be concluded that the ultrasound influenced the properties of the soy-based desserts. The ultrasound promoted significant differences in SSC, rheology, particle size, and $W H C$ among the samples. Moreover, considerable alterations were observed in the microstructure of the US-treated samples when compared with the untreated sample, and the results can be related to structural changes or breaking of some components as proteins, starch, and polysaccharides, and also of interactions between the components. However, the ultrasound had no effect on $\mathrm{pH}$, colour, and percentage of hysteresis area. After 60 days under refrigerated storage, all evaluated properties differed significantly, except for the $\mathrm{pH}$. Properties as mean particle size, consistency index, and the relation $G^{\prime} / G^{\prime \prime}$ decreased during the storage, unlike the flow index values and percentage of hysteresis area values that increased with time. Although more studies on ultrasound are required, it can be concluded that the ultrasound has the advantage of changing the texture of the dessert, reducing its viscosity without causing negative impacts on essential properties as water holding capacity.

\section{References}

AOAC (2000a). Official methods of analysis, Gaithesburg, United States. No. 932.12.

AOAC (2000b). Official methods of analysis, Gaithesburg, United States. No. 981.12.

AzIZI, R. \& FARAHNAKY, A. (2013): Ultrasound assisted cold gelation of kappa carrageenan dispersions. Carbohyd. Polym., 95, 522-529.

Bates, D.M., Bagnall, W.A. \& Bridges, M.W. (2006): Method of treatment of vegetable matter with ultrasonic energy. US patent application 20060110503.

Bermudez-Aguirre, D., Corradini, M.G., Mawson, R. \& Barbosa-Canovas, G.V. (2009a): Modelling the inactivation of Listeria innocua in raw whole milk treated under thermo-sonication. Innov. Food Sci. Emerg., $10,172-178$.

Bermudez-Aguirre, D., Mawson, R., Versteeg, K. \& Barbosa-Canovas, G.V. (2009b): Composition properties, physicochemical characteristics and shelf life of whole milk after thermal and thermo-sonication treatments. J. Food Quality, 32, 283-302.

Brasil (2001): Ministério da Saúde. Agência Nacional de Vigilância Sanitária. Resolução n 12, de 02 de janeiro de 2001. http://portal.anvisa.gov.br.

BRUMMER, R. (2006): Rheology essentials of cosmetic and food emulsions. Berlin: Springer. 180 pages.

Ciron, C.I.E., Gee, V.L., Kelly, A.L. \& Auty, M.A.E. (2010): Comparison of the effects of high-pressure microfluidization and conventional homogenization of milk on particle size, water retention and texture of non-fat and low-fat yoghurts. Int. Dairy J., 20, 314-320.

CzanK, C., Simmer, K. \& Hartmann, P.E. (2010): Simultaneous pasteurization and homogenization of human milk by combining heat and ultrasound: Effect on milk quality. J. Dairy Res., 77, 183-189.

Harte, F., Luedecke, L., Swanson, B. \& Barbosa-Canovas, G.V. (2003). Lowfat set yoghurt made from milk subjected to combinations of high hydrostatic pressure and thermal processing. J. Dairy Sci., 86, 1074-1082. 
HuANG, Q., Li, L. \& Fu, X. (2007): Ultrasound effects on the structure and chemical reactivity of cornstarch granules. Starch/Stärke, 59, 371-378.

Huang, Y.Y. \& Terentjev, E.M. (2012): Dispersion of carbon nanotubes: Mixing, sonication, stabilization, and composite properties. Polymers, 4, 275-295.

Iida, Y., Tuziuti, T., Yasui, K., Towata, A. \& KozuKa, T. (2008): Control of viscosity in starch and polysaccharide solutions with ultrasound after gelatinization. Innov. Food Sci. Emerg., 9(2), 140-146.

Innocente, N., Biasutti, M., Venir, E., Spaziani, M. \& Marchesini, G. (2009): Effect of high-pressure homogenization on droplet size distribution and rheological properties of ice cream mixes. J. Dairy Sci., 92, 1864-1875.

Jambrak, A.R., Herceg, Z., Šubarić, D., Babić, J., Brnčić, M. \& Brnčić, S.R. (2010): Ultrasound effect on physical properties of corn starch. Carbohyd. Polym., 79(1), 91-100.

Jambrak, A.R., Lelas, V., Mason, T.J., Kresic, G. \& BadanjaK, M. (2009): Physical properties of ultrasound treated soy proteins. J. Food Eng., 93, 386-393.

Kresic, G., Lelas, V., Jambrak, A.R., Herceg, Z. \& Brncic, S.R. (2008): Influence of novel food processing technologies on the rheological and thermophysical properties of whey proteins. J. Food Eng., 87, 64-73.

LAPASIN, R. \& PRICL, S. (1995): Rheology of industrial polysaccharides: Theory and applications. Blackie Academic and Processional, Chapman \& Hall, London. 620 pages.

Lit, C.-Y., Chen, C.-H., Yeh, A.-I. \& Laic, V.M.-F. (1999): Preliminary study on the degradation kinetics of agarose and carrageenans by ultrasound. Food Hydrocolloids 13, 477-481.

LiM, K.S. \& BARIGOU, M. (2005): Pneumatic foam generation in the presence of a high-intensity ultrasound field. Ultrason. Sonochem., 12, 385-390.

Luo, Z., Fu, X., He, X., Luo, X., GAo, Q. \& Yu, S. (2008): Effect of ultrasonic treatment on the physicochemical properties of maize starches differing in amylose content. Starch/Stärke, 60, 646-653.

Mason, T.M. \& Zнао, Y. (1994): Enhanced extraction of tea solids using ultrasound. Ultrasonics, 32(5), 375-377.

Melgosa, M., Perez, M., Yebra, A., Huertas, A. \& Hita, E. (2001): Algunas reflexiones y recientes recomendaciones internacionales sobre evaluación de diferencias de color (Some thoughts and recent international recommendations on evaluation of color differences). Óptica pura y Aplicada, 34, 1-10.

Montalbo-Lomboy, M., Khanal, S.K., Van Leeuwen, J., Raj Raman, D., Dunn Jr, L. \& Grewell, D. (2010): Ultrasonic pretreatment of corn slurry for saccharification: A comparison of batch and continuous systems. Ultrason. Sonochem., 17(5), 939-946.

Silva, V.M., Kawazoe Sato, A.C., Barbosa, G., Dacanal, G., Ciro-Velásquez, H.J. \& Lopes Cunha, R. (2010): The effect of homogenisation on the stability of pineapple pulp. Int. J. Food Sci. Tech., 10, 2127-2133.

Spada, J.C., Marczak, L.D.F., Tessaro, I.C., Flôres, S.H. \& Cardozo, N.S.M. (2014): Rheological modelling, microstructure and physical stability of custard-like soy-based desserts enriched with guava pulp. CyTA Journal of Food, http://dx.doi.org/10.1080/19476337.2014.987698, 13(3), 373-384.

SuJKA, M. \& JAMroZ, J. (2013): Ultrasound-treated starch: SEM and TEM imaging, and functional behaviour. Food Hydrocolloids, 31(2), 413-419.

TAN, M.C., Chin, N.L. \& Yusof, Y.A. (2011): Power ultrasound aided batter mixing for sponge cake batter. J. Food Eng., 104, 430-437. 